\title{
ON THE INORGANIC CONSTITUENTS OF THE SKELETONS OF TWO RECENT CRINOIDS.
}

\author{
By Austin Hobart Clark, \\ Assistant Curator, Division of Marine Invertebrates.
}

Dr. Chase Palmer, of the U. S. Geological Survey, has recently been so kind as to make for me, under the direction of Prof. F. W. Clarke, analyses of the chief inorganic constituents of the skeletons of two recent crinoids, taken under very different conditions of temperature and light, but at nearly the same depth, and consequently at nearly the same pressure.

While there has been a considerable amount of work done in regard to the determination of the elements of the skeleton of many marine animals, more particularly corals and mollusks, there is only a single record to be found among the recent crinoids. In $1906 \mathrm{Mr}$. Henry W. Nichols ${ }^{a}$ analyzed some pinnulate arms from a specimen of Metacrinus rotundus from southern Japan (probably Sagami Bay), and he found that the skeleton contained 11 per cent of magnesium carbonate, a greater proportion than had been detected in the skeleton of any marine animal previously examined.

The material submitted to Doctor Palmer consisted of pinnulate arms of Metacrinus rotundus from the Eastern Sea and of Heliometra maxima from the Sea of Okhotsk. Both specimens were air dried from alcoholic examples collected by myself in 1906 .

\section{METACRINUS ROTUNDUS.}

Metacrinus rotundus P. H. Carpenter, Trans. Linn. Soc. (Zool.), (2), vol. 2, 1885 , p. 436 , pl. 50 ; pl. 52, figs. $1-7$.

Locality.-Albatross station 4934; lat. $30^{\circ} 58^{\prime} 30^{\prime \prime}$ N.; long. $130^{\circ}$ $32^{\prime} 00^{\prime \prime}$ E. (Sata Misaki light bearing N. $77 \frac{1}{2}^{\circ}$ E., 7 miles distant), in the Eastern Sea off Kogoshima Gulf; depth, 152-103 fathoms; bottom temperature, about $56^{\circ} \mathrm{F}$.; surface temperature, $84^{\circ} \mathrm{F}$.; surface density, 1.02355 .

This is the same species as that analyzed by Nichols. It is probable that the depth is somewhat greater and the temperature slightly less 
than in the habitat of his specimen, which I suspect was a commercial specimen obtained through Mr. Alan Owston from Japanese fishermen living at Sagami Bay.

In the sample examined by him Doctor Palmer found the proportions of $\mathrm{CaO}$ and $\mathrm{MgO}$ to be as follows:

$\mathrm{CaO}=49.95 \%$ (equivalent to $\mathrm{CaCO}_{3} 89.19 \%$ );

$\mathrm{MgO}=4.89 \%$ (equivalent to $\mathrm{MgCO}_{3} 10.29 \%$ ).

He notes, further, that "this specimen is white and quite free from extraneous material."

\section{HELIOMETRA GLACIALIS var. MAXIMA.}

Antedon eschrichtii var. maxima A. H. Clark, Proc. U. S. Nat. Mus., vol. 33, 1907, p. 75.

Locality.-Albatross station 4986 ; lat. $43^{\circ} 01^{\prime} 40^{\prime \prime} \mathrm{N}$.; long. $140^{\circ}$ $22^{\prime} 40^{\prime \prime}$ E. (Benkei Mizaki light bearing N. $35^{\circ}$ E., 15 miles distant), in Iwanai Bay, northeastern part of the Sea of Japan; depth, 172 fathoms; bottom temperature, $33.9^{\circ} \mathrm{F}$.; surface temperature, $69^{\circ} \mathrm{F}$.; surface density, 1.02405 .

In this specimen Doctor Palmer found:

$\mathrm{CaO}=40.03 \%$ (equivalent to $\mathrm{CaCO}_{3} 71.48 \%$ );

$\mathrm{MgO}=2.68 \%$ (equivalent to $\mathrm{MgCO}_{3} 5.61 \%$ ):

and he adds that "this specimen contains much foreign material, chiefly organic; on the basis of purity as found in the other specimen, the content of magnesium carbonate $\left(\mathrm{MgCO}_{3}\right)$ in this specimen may be accepted as 7 per cent."

This species is the largest crinoid known, measuring about three feet across its extended arms. It might be supposed that the comparative openness of its skeleton was due to this very large size as a result of the deposition of inorganic matter not keeping pace with the rapid increase in bodily size. It is noticeable, however, that the crinoids of the deep seas and from the colder regions have more delicate and more open skeletons than those from comparatively shallow water in the tropics, and it therefore seems most probable that cold has the effect of retarding the deposition of inorganic matter by the animals to a far greater degree than it retards the general body development. Probably in the deep-water forms the enormous pressure under which the animals live also tends in various ways to make the deposition of inorganic matter more difficult; but from the fact that among the crinoids the skeletal conditions found in the inhabitants of the deep sea are to almost or quite the same degree repeated or continued in those of the polar regions points to the conclusion that the chief factor involved is temperature rather than pressure. 


\section{$2 \mathrm{BHL}$ Biodiversity Heritage Library}

Clark, Austin Hobart. 1911. "On the inorganic constituents of the skeletons of two Recent crinoids." Proceedings of the United States National Museum 39(1795), 487-488. https://doi.org/10.5479/si.00963801.39-1795.487.

View This Item Online: $\underline{\text { https://www.biodiversitylibrary.org/item/53443 }}$

DOI: https://doi.org/10.5479/si.00963801.39-1795.487

Permalink: https://www.biodiversitylibrary.org/partpdf/51987

\section{Holding Institution}

Smithsonian Libraries

\section{Sponsored by}

Smithsonian

\section{Copyright \& Reuse}

Copyright Status: Public domain. The BHL considers that this work is no longer under copyright protection.

This document was created from content at the Biodiversity Heritage Library, the world's largest open access digital library for biodiversity literature and archives. Visit BHL at https://www.biodiversitylibrary.org. 